\title{
Pematahan Dormansi Rimpang Kaempferia parvifloraWall. ExBaker
}

\author{
RhizomeDormancyBreaking of KaempferiaparvifloraWall. ExBaker
}

\section{Muaz Abdul Karim, SinthoWahyuningArdie*, dan Nurul Khumaida}

\author{
Departemen Agronomi dan Hortikultura, Fakultas Pertanian, Institut Pertanian Bogor \\ (Bogor Agricultural University), Jl. Meranti, Kampus IPB Darmaga, Bogor 16680, Indonesia \\ Telp.\&Faks.62-251-8629353 e-mail agronipb@indo.net.id \\ * Penulis korespondensi: sinthoardie@gmail.com
}

Disetujui 24 Desember 2013/ Published online 13 Februari 2014

\begin{abstract}
Kaempferiaparviflora (Zingiberaceae family) has a potency to be developed for a new medicinal plants in Indonesia. One of problems in its cultivation is the lack of planting material availability due to the long dormant period. The objectives of this research were to study the effect of various concentrations of $B A P$ and ethephon, and also the effect of the prior growing condition to the dormancy breaking and shoot growth of K.parviflora rhizome. Two separate experiments were applied for two lots of rhizomes namely Cikabayan and Pasir Sarongge lots. Each experiment was arranged in completely random design with 2 factors. Experiment-1 used 4 concentrations of $B A P(0,50,100$, and $150 \mathrm{ppm})$ as the first factor. While, experiment-2 used 5 concentrations of ethephon (0,200, 400, 600 and 800 ppm) as the first factor. The second factor in both experiments were prior shade condition at 55\% artificial shading and natural shading. A rhizome without soaked application (control) and a rhizome with soaked by aquadestilata without PGRs (O ppm) were used as compared items. Data was analyzed with ANOVA. Combined Analysis of Variance and ttest were performed in order to compare between 2 lots. Result showed that concentration of BAP until 150 ppm and concentration of ethephon until 800 ppm were not effective to stimulate bud induction time. Meanwhile, rhizome from 55\% artificial shading had a shorter periode of dormancy than the natural shading. In the addition, plants from Pasir Sarongge rhizomes lot had more plant number, plant height, leaf number, leaf length, and leaf width than Cikabayan rhizomes lot.
\end{abstract}

Key words: benzylaminopurine, ethephon, shading, PGR, Zingiberaceae

\section{ABSTRAK}

Kaempferiaparviflora (famili Zingiberaceae) berpotensi dikembangkan menjadi produk kesehatan baru di Indonesia. Salah satu permasalahan dalam budi dayanya adalah terbatasnya persediaan bahan tanam. Tujuan penelitian ini adalah menguji pengaruh konsentrasi BAP dan etepon, serta pengaruh kondisi

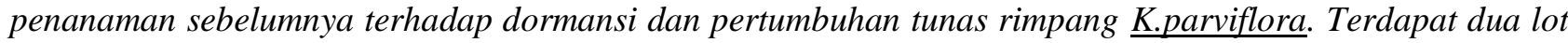
rimpang yang diuji pada penelitian ini, yaitu lot Cikabayan dan lot Pasir Sarongge. Setiap lot rimpang memiliki 2 percobaan terpisah yaitu pematahan dormansi (1) menggunakan BAP, dan (2) menggunakan etepon. Percobaan disusun berdasarkan rancangan acak lengkap (RAL) faktorial dengan 2 faktor. Faktor pertama dalam percobaan-1 adalah konsentrasi BAP yang terdiri atas 4 taraf yaitu 0, 50, 100 dan 150 ppm. Faktor kedua adalah kondisi asal naungan pada penanaman sebelumnya dengan 2 taraf yaitu naungan buatan 55\% dan naungan tajuk. Faktor pertama pada percobaan-2 adalah konsentrasi etepon yang terdiri atas 5 taraf yaitu 0, 200, 400, 600 dan 800 ppm. Faktor kedua adalah kondisi asal naungan pada penanaman sebelumnya yang terdiri atas 2 taraf yaitu naungan buatan 55\% dan naungan tajuk. Rimpang tanpa perlakuan perendaman (kontrol) dan rimpang dengan perlakuan perendaman aquadestilata tanpa ZPT (O ppm) digunakan sebagai pembanding. Data dianalisis dengan uji-F. Analisis ragam gabungan dan uji-t dilakukan untuk membandingkan antara kedua lot. Hasil menunjukkan bahwa konsentrasi BAP sampai dengan 150 ppm dan konsentrasi etepon sampai dengan 800 ppm belum cukup efektif menstimulasi waktu rimpang bertunas. Kondisi asal naungan buatan 55\% menghasilkan waktu rimpang bertunas yang lebih cepat dibandingkan naungan tajuk, namun naungan tajuk menghasilkan jumlah tanaman tanaman, tinggi 
tanaman, panjang daun, dan lebar daun yang lebih besar dibandingkan naungan buatan 55\%. Tanaman yang berasal dari lot rimpang Pasir Sarongge memiliki jumlah tanaman, tinggi tanaman, jumlah daun, panjang daun, dan lebar daun yang lebih besar dibandingkan tanaman dari lot rimpang Cikabayan.

Kata kunci: benzylaminopurine, etepon, naungan, Zingiberaceae, ZPT

\section{PENDAHULUAN}

Kaempferia parviflora Wall. exBaker (kencur hitam) adalah salah satu tanaman genus Kaempferia (Techaprasan et al. 2010) yang berpotensi dikembangkan menjadi produk kesehatan baru di Indonesia. Beberapa khasiat kesehatan yang dimiliki oleh $K$. parvifloradi antaranya untuk mengobati dan mencegah penyakit kanker, inflamasi, gangguan pencernaan, dan penyakit lambung (Leardkamolkarn et al. 2009; Tewtrakul et al. 2009; Chaichanawongsaroj et al. 2011). Walau demikian, budi daya tanaman $K$. parviflora di Indonesia masih sangat terbatas.

Penelitian sebelumnya telah menunjukkan bahwa K. Parviflora tumbuh baik pada kondisi ternaung dan dengan adaptasi elevasi yang cukup luas antara 240-1200 m dpl (Evi, 2012). Pertumbuhan vegetatif awal terbaik dicapai pada kondisi budi daya di bawah naungan tajuk dengan ketinggian $240 \mathrm{~m}$ dpl, tetapi pertumbuhan vegetatif akhirdan produksi rimpang terbaik dicapai pada kondisi budi daya dengan ketinggian 1200 mdpl pada naungan tajuk (Rahma, 2013). Aplikasi pupuk hayati dalam praktek budi dayanya dengan dosis $15 \mathrm{~L} \mathrm{ha}^{-1}$ dan dosis $50 \%$ pupuk kimia (150 kg ha-1 urea, $125 \mathrm{~kg} \mathrm{ha}^{-1} \mathrm{SP}-36$, dan $125 \mathrm{~kg} \mathrm{ha}^{-1} \mathrm{KCl}$ )dapat meningkatkan pertumbuhan vegetatif akhir yang lebih baik dibandingkan tanpa penggunaan pupuk hayatisampai dengan umur tanam 29 MST (Zulfa, 2012).Kaempferia parvifloramemproduksi rimpang dan dapat dipanen pada umur tanam 1214bulan setelan tanam (BST).

Salah satu permasalahan dalam budi daya $K$. parviflorasaat ini adalah terbatasnya ketersediaan bahan tanam.Bahan tanam $K$. Parviflora adalah organ rimpang. Rimpang ini memiliki periode dormansi sebelum dapat siap digunakan sebagai bahan tanam.Tanaman Kaempferia galanga memiliki periode dormansi yang berkisar 2-3 bulan (Rostiana dan Effendi, 2007). Penyingkatan periode dormansi akan dapat mempercepat siklus produksi tanaman, sehingga metode pematahan dormansi rimpang $K$. parviflora perlu dikembangkan.

Sitokinin dan etilen merupakan zat pengatur tumbuh (ZPT) yang mempengaruhi pertumbuhan dan perkembangan tanaman dengan konsentrasi yang cukup kecil (Heddy, 1986). Salah satu jenis sitokinin yang sering digunakan adalah BAP (6benzylaminopurin), sedangkan etepon merupakan nama dagang untuk etilen. Thohirah et al. (2010) menunjukkan bahwa perlakuan perendaman dengan 100 ppm BAP dan 600 ppm etepon dapat dengan nyata mempersingkat periode dormansi rimpang dan meningkatkan jumlah tunas Curcuma alismatifolia.

Pertumbuhan tanaman yang diperbanyak menggunakan rimpang juga dipengaruhi oleh kualitas rimpang. Rimpang yang berukuran besar dan memiliki akar adventif dapat lebih mudah tumbuh menjadi tanaman (Hartmann dan Kester 1959). Rahma (2013) melaporkan bahwa tanaman di bawah naungan tajuk pada daerah elevasi tinggi mampu memproduksi rimpang dengan ukuran yang lebih besar dibandingkan budi daya pada elevasi rendah. Oleh sebab itu perlu diketahui apakah kondisi penanaman sebelumnya berpengaruh terhadap pertumbuhan tanaman selanjutnya.

Saat ini belum terdapat studi mengenai pematahan dormansi rimpang $K$. parviflora. Tujuan dari penelitian adalah untuk mempelajari pengaruh konsentrasi BAP dan etepon terhadap periode dormansi dan pertumbuhan tunas rimpang $K$. parviflora, dan juga untuk mempelajari pengaruh kondisi penanaman sebelumnya terhadap dormansi dan pertumbuhan rimpang $K$. parviflora.

\section{BAHAN DAN METODE}

Penelitian telah dilaksanakan pada bulan Maret sampai November 2012 di Laboratorium Pascapanen Departemen Agronomi dan Hortikultura, IPB.Bahan rimpang $K$. parviflora yang digunakan pada penelitian ini berasal dari 2 lot hasil tanaman pada penelitian sebelumnya di Kebun Percobaan Cikabayan (240 m dpl) dan Kebun Percobaan Pasir Sarongge (1 $200 \mathrm{~m} \mathrm{dpl}$ ). Kondisi naungan tanaman pada tiap kebun tersebut terdiri dari naungan buatan 55\% dan naungan tajuk. Naungan tajuk merupakan kondisi di bawah naungan pohon jeruk pada Kebun Percobaan Cikabayan dan pohon alpukat pada Kebun Percobaan Pasir Sarongge (Evi 2012; Rahma 2013). Bahan yang digunakan untuk 
pematahan dormansi rimpang adalah BAP dan etepon. Alat yang digunakan dalam pengamatan adalah thermo-hygrometer, jangka sorong, timbangan dan penggaris.

Terdapat dua percobaan terpisah pada masing-masing lot rimpang,yaitu (1)pematahan dormansi menggunakan BAP, dan (2) pematahan dormansi menggunakan etepon yang merujuk pada metodeThohirah et al. (2010). Setiap percobaan disusun berdasarkan rancangan acak lengkap faktorial dengan dua faktor. Faktor pertama dalam percobaan-1 adalah konsentrasi BAP yang terdiri atas 4 taraf, yaitu $0,50,100$ dan $150 \mathrm{ppm}$. Faktor kedua adalah kondisi asal naungan pada penanaman sebelumnya, yaitu naungan buatan 55\%, dan naungan tajuk.Faktor pertama pada percobaan-2 adalah konsentrasi etepon yang terdiri atas 5 taraf, yaitu 0, 200, 400, 600 dan 800 ppm. Faktor kedua adalah kondisi asal naungan pada penanaman sebelumnya, yaitu naungan buatan 55\%, dan naungan tajuk. Rimpang tanpa perlakuan perendaman (kontrol) dan dengan perlakuan perendaman aquadestilata tanpa ZPT $\left(\begin{array}{lll}0 & \mathrm{ppm}) & \text { digunakan sebagai }\end{array}\right.$ pembanding.

Penelitian dimulai dengan mengelompokkan rimpang berdasarkan bobot. Setiap perlakuan menggunakan 3 rimpang berukuran sedang (bobot 5.19-10.38 g) dan 2 rimpang berukuran besar (bobot $>10.38 \mathrm{~g}$ ). Bobot rimpang dihitung pada awal dan akhir pengamatan. $\mathrm{NaOH} \quad 0.1 \quad \mathrm{M}$ digunakan untuk melarutkan BAP sebelum dicampur dengan aquadestilata. Perlakuan BAP/etepon dilakukan dengan cara merendam rimpang pada larutan steril BAP/etepon selama 30 menit. Rimpang kemudian diangkat dan disimpan pada tampah bambu. Tampah disimpan dalam kondisi suhu ruang $\pm 28{ }^{\circ} \mathrm{C}$ selama 90 hari.Setelah tunas rimpang muncul dan berukuran panjang $\geq 5 \mathrm{~cm}$, rimpang ditanam di dalam pot berdiameter $15 \mathrm{~cm}$ dengan media kompos. Tanaman $K$. parviflora dipelihara dan diamati sampai dengan umur 8 minggu setelah tanam (MST).Penyiraman dilakukan secara manual setiap 4 harisekali mengacu pada budi daya kencur(Indriati 2006).

Karakter pertumbuhan tunas rimpang diamati setiap 2 hari sekali hingga 90 hari setelah perlakuan (HSP) terhadap parameter berikut:(1) waktu rimpang bertunas, (2) jumlah tunas, (3) panjang tunas, dan(4) penyusutan bobot rimpang. Karakter pertumbuhan tanaman diamati setiap pekan setelah rimpang ditanam sampai tanaman berumur 8 MST terhadap parameter:(1) jumlah tanaman per rumpun, (2) tinggi tanaman, (3) jumlah daun per tanaman, (4) panjang daun, dan(5) lebar daun.Pengamatan kondisi ruang meliputi suhu dan kelembabaan harian dilakukan berdasarkan metode Handoko (1993).Data dianalisis menggunakan uji-F. Jika hasil menunjukkan pengaruh nyata, maka dilakukan uji lanjut DMRT pada $\alpha=5 \%$. Analisis ragam gabungan dan uji-t dilakukan untuk membandingkan pengaruh pada kedua lot rimpang.

\section{HASIL DAN PEMBAHASAN}

Penelitian ini menggunakan rimpang yang berasal dari 2 lokasi berbeda pada penelitian sebelumnya, yaitu KP Cikabayan ( $240 \mathrm{~m} \mathrm{dpl}$ ) dan KP Pasir Sarongge $\quad$ (1 $200 \mathrm{~m} \mathrm{dpl)} \mathrm{(Evi} \mathrm{2012;}$ Rahma 2013). Perbedaan kedua lokasi tersebut menyebabkan variasi terhadap waktu panen, produksi rimpang, jumlah akar tanaman, jumlah anakan rimpang, bobot rimpang, dan ukuran rimpang. Tanaman lot Cikabayan memiliki waktu panen yang lebih cepat dibandingkan lot Pasir Sarongge. Rimpang lot Cikabayan dapat dipanen pada 12 bulan setelah tanam (BST), sedangkan lot Pasir Sarongge dapat dipanen pada 14 BST (Rahma 2013). Hal tersebut menjadikan rimpang yang berasal dari lot Cikabayan dan Pasir Sarongge diuji dalam lot terpisah.

Rahma (2013) melaporkan bahwa rimpang yang berasal dari lot Pasir Sarongge memiliki ukuran yang lebih besar dibandingkan rimpang yang berasal dari lot Cikabayan. Rata-rata bobot rimpang pada lot Pasir Sarongge sebesar $23.01 \mathrm{~g}$, dengan bobot maksimum $52.84 \mathrm{~g}$ dan bobot minimum $10.11 \mathrm{~g}$. Bobotrimpang lot Cikabayan berkisar 3.72-20.22 g, dengan rata-rata $10.54 \mathrm{~g}$. Oleh sebab itu rimpang lot Pasir Sarongge yang digunakan pada penelitian ini didominasi oleh rimpang besar (bobot > $10.38 \mathrm{~g}$ ). Selain itu, kondisi naungan tajuk pada penanaman sebelumnya juga telah menghasilkan bobot rimpang yang lebih besar dibandingkan kondisi naungan buatan $55 \%$.

Perlakuan perendaman BAP dan etepon dilakukan pada lot Cikabayan saat rimpang berumur 26 hari setelah panen, dan pada lot Pasir Sarongge saat rimpang berumur 15 hari setelah panen. Suhu ruang harian selama penyimpanan di Laboratorium Pascapanen berkisar 26.0-28.8 ${ }^{\circ} \mathrm{C}$ dengan rataan sebesar $27.3{ }^{\circ} \mathrm{C}$, dan kelembaban udara berkisar $61.7-83.0 \%$ dengan rata-rata $73.2 \%$.

Cendawan menyerang beberapa rimpang yang digunakan dalam penelitian ini dengan gejala bintik putih pada permukaan rimpang. 
Hasil identifikasi menunjukkan bahwa cendawan yang menyerang rimpang adalah Phytomices. Cendawan tersebut tidak menyebabkan kerusakan signifikan pada rimpang, namun saat rimpang sudah bertunas cendawan dapat merusak tunas dan menyebar ke permukaan tunas. Kejadian penyakit yang disebabkan oleh Phytomices pada lot Cikabayan adalah sebesar $18 \%$ untuk bahan Percobaan-1 dan $17.5 \%$ untuk bahan Percobaan-2, sedangkan pada lot Pasir Sarongge cendawan menyerang hampir seluruh rimpang. Penanggulangan penyakit dilakukan dengan cara merendam rimpang yang terserang pada fungisida (mankozeb 80\%) dan bakterisida (streptomisin sulfat 20\%) dengan konsentrasi $20 \mathrm{~g} \mathrm{l}^{-1}$ selama 510 menit.

Rimpang yang telah ditanam dalam pot disimpan pada rak tanam dengan atap pelindung plastik bening untuk melindungi tanaman dari intensitas cahaya matahari yang terlalu besar dan hujan. Suhu rata-rata pada lingkungan tanam adalah $32{ }^{\circ} \mathrm{C}$ dengan kelembaban sebesar $69 \%$. Beberapa hama menyerang tanaman saat penyimpanan dan menyebabkan kerusakan pada tanaman. Hama yang menyerang adalah kutu putih (Pseudococcusspp.) dan belalang (Dissosteiracaroline). Penanggulangan hama dilakukan secara manual.

\section{Percobaan 1: Pematahan Dormansi Rimpang} Kaempferia parvifloraWall. ExBaker dengan BAP

\section{Pengaruh Konsentrasi BAP terhadap Pertumbuhan Tunas RimpangK. Parviflora}

Pematahan dormansi dapat ditandai dengan tumbuhnya tunas pada rimpang. Rata-rata waktu pemunculan tunas pada kedua lot rimpang $K$. parviflora berkisar 15.5-56.4 HSP (Tabel 1). Jika waktu pemunculan tunas dihitung sejak panen, rimpang lot Cikabayan tanpa perlakuan apapun (kontrol tidak direndam) mulai bertunas pada 55.4 hari setelah panen dan rimpang lot Pasir Sarongge pada 50.2 hari setelah panen. Rimpang yang diberi perlakuan perendaman memiliki rata-rata waktu pemunculan tunas 38.5 HSP untuk lot Cikabayan dan 45.2 HSP untuk lot Pasir Sarongge. Hasil uji-t menunjukkan bahwa rimpang dengan aplikasi perendaman tidak berbeda nyata dibandingkan rimpang tanpa perendaman terhadap waktu rimpang bertunas. Secara umum konsentrasi BAP tidak berpengaruh nyata terhadap waktu pemunculan tunas rimpang $K$. parviflora.

Tabel 1. Pengaruh konsentrasi BAP terhadap waktu rimpang bertunas dan penyusutan bobot rimpang $K$. parviflora

\begin{tabular}{llllcccccc}
\hline \multirow{2}{*}{$\begin{array}{l}\text { Konsentrasi } \\
\text { BAP }(\mathrm{ppm})\end{array}$} & \multicolumn{3}{c}{$\begin{array}{c}\text { Waktu rimpangbertunas } \\
\text { (HSP) }\end{array}$} & \multicolumn{3}{c}{$\begin{array}{c}\text { Penyusutanbobot } \\
\text { rimpang }(\mathrm{g})\end{array}$} & \multicolumn{3}{c}{$\begin{array}{c}\text { Persentase penyusutan bobot } \\
\text { rimpang(\%) }\end{array}$} \\
\cline { 2 - 10 } & Lot C & Lot PS & Rataan & Lot C & Lot PS & Rataan & Lot C & Lot PS & Rataan \\
\hline Kontrol & 29.4 & 35.2 & 31.5 & 3.08 & 7.11 & 5.10 & 31.70 & $31.60 \mathrm{a}$ & $31.65 \mathrm{a}$ \\
0 & 39.3 & 30.0 & 35.7 & 2.48 & 5.89 & 4.18 & 25.70 & $23.60 \mathrm{c}$ & $24.65 \mathrm{~b}$ \\
50 & 56.4 & 15.5 & 41.6 & 2.18 & 4.91 & 3.62 & 21.89 & $25.70 \mathrm{bc}$ & $23.89 \mathrm{~b}$ \\
100 & 37.3 & 32.0 & 34.9 & 2.28 & 5.97 & 4.13 & 28.20 & $29.60 \mathrm{a}$ & $28.90 \mathrm{ab}$ \\
150 & 19.5 & 43.3 & 29.7 & 2.48 & 5.51 & 4.26 & 24.42 & $22.00 \mathrm{a}$ & $23.00 \mathrm{~b}$ \\
\hline Rataan & 35.7 & 32.3 & & $2.51 \mathrm{~B}$ & $5.88 \mathrm{~A}$ & & 26.61 & 26.50 & \\
\hline Direndam vs & & & & & & & & &
\end{tabular}

Direndam vs

kontrol tidak tn tn th tn th th th th th

direndam

HSP = Hari setelah perlakuan; C = Cikabayan; PS = Pasir Sarongge; Seluruh data ditransformasi dengan rumus $\sqrt{\mathrm{x}+0.5}$; Angka yang ditampilkan adalah nilai rataan sebelum transformasi; Nilai yang diikuti dengan huruf yang sama pada kolom yang sama menunjukkan tidak berbeda nyata berdasarkan DMRT pada $\alpha=5 \%$. Nilai yang diikuti dengan huruf kapital yang sama pada tiap peubah menunjukkan tidak berbeda nyata berdasarkan analisis ragam gabungan; $\mathrm{tn}=$ tidak berbeda nyata berdasarkan uji-t.

Konsentrasi BAP berpengaruh nyata terhadap persentase penyusutan bobot rimpang Pasir Sarongge (Tabel 1). Hasil analisis ragam gabungan menunjukkan bahwa rimpang lot Pasir Sarongge memiliki penyusutan bobot yang lebih besar dibandingkan rimpang lot Cikabayan. Rimpang dengan konsentrasi BAP sebesar 150, 50, dan $0 \mathrm{ppm}$ memiliki persentase penyusutan bobot lebih kecil dibandingkan kontrol, namun tidak berbeda nyata terhadap konsentrasi BAP 100 ppm. 
Thohirah et al. (2010) melaporkan bahwa konsentrasi BAP sebesar 100 ppm dapat mempercepat waktu bertunas $C$. alismatifolia yaitu 2.2 hari lebih cepat dibandingkan waktu bertunas yang tidak diberi BAP yaitu 5.5 hari. Hasil penelitian ini menunjukkan bahwa BAP sampai dengan konsentrasi $150 \mathrm{ppm}$ belum efektif menstimulasi waktu pemunculan tunas rimpang $K$. parviflora, dan waktu bertunas rimpang $K$. parviflora lebih lama dibandingkan $C$. alismatifolia tanpa perlakuan apapun. Perbedaan waktu rimpang $K$. parviflora bertunas tersebut secara agronomis cukup berarti. Konsentrasi BAP sebesar $150 \mathrm{ppm}$ pada lot Cikabayan dapat menghasilkan waktu pemunculan tunas yang lebih cepat hingga 10 hari, dan konsentrasi BAP sebesar $50 \mathrm{ppm}$ pada lot Pasir Sarongge dapat menghasilkan waktu pemunculan tunas yang lebih cepat hingga 20 hari dibandingkan kontrol.

Konsentrasi BAP sebesar $150 \mathrm{ppm}$ pada lot Cikabayan menghasilkan jumlah tunas yang lebih banyak dibandingkan dengan konsentrasi 100 dan 50 ppm saat umur 40-50 HSP, tetapi tidak berbeda nyata terhadap pembanding (Tabel 2). Konsentrasi BAP sebesar $150 \mathrm{ppm}$ juga menghasilkan tunas yang lebih panjang saat umur 20-90 HSP (Gambar 1). Jumlah dan panjang tunas pada lot Pasir Sarongge tidak dipengaruhi oleh BAP. Rata-rata jumlah tunas yang diperoleh untuk lot Pasir Sarongge saat 90 HSP adalah 0.9 dengan rata-rata panjang tunas sebesar $1.71 \mathrm{~cm}$.

Hasil penelitian ini menunjukkan bahwa peningkatan konsentrasi BAP pada rimpang $K$. parviflora lot Cikabayan dapat meningkatkan laju pertumbuhan tunas dan jumlah tunas. Thohirah $e t$ al. (2010) melaporkan sebaliknya bahwa konsentrasi BAP tidak berpengaruh nyata terhadap panjang tunas $C$. alismatifolia. Selain itu, pertumbuhan tunas pada rimpang $C$. xanthorrhiza dapat dibantu hanya dengan perendaman dalam air (Djamhari 2010).

Tabel 2. Pengaruh konsentrasi BAP terhadap jumlah tunas lot rimpang Cikabayan

\begin{tabular}{|c|c|c|c|c|c|c|c|c|c|}
\hline \multirow{2}{*}{$\begin{array}{l}\text { Konsentrasi BAP } \\
\text { (ppm) }\end{array}$} & \multicolumn{9}{|c|}{ Umur (hari setelah perlakuan) } \\
\hline & 10 & 20 & 30 & 40 & 50 & 60 & 70 & 80 & 90 \\
\hline & \multicolumn{9}{|c|}{ Jumlah tunas muncul } \\
\hline Kontrol & 0.6 & 0.7 & 0.8 & $1.1 \mathrm{a}$ & $1.1 \mathrm{a}$ & 1.1 & 1.1 & 1.2 & 1.2 \\
\hline 0 & 0.6 & 0.6 & 0.7 & $0.7 \mathrm{ab}$ & $0.7 \mathrm{ab}$ & 0.8 & 0.8 & 0.9 & 1.0 \\
\hline 50 & 0.2 & 0.2 & 0.2 & $0.2 b$ & $0.2 \mathrm{~b}$ & 0.3 & 0.7 & 0.7 & 0.8 \\
\hline 100 & 0.4 & 0.4 & 0.4 & $0.5 b$ & $0.5 b$ & 0.5 & 0.5 & 0.7 & 0.9 \\
\hline 150 & 0.7 & 0.7 & 0.8 & $0.8 \mathrm{a}$ & $0.9 \mathrm{a}$ & 0.9 & 0.9 & 0.9 & 0.9 \\
\hline
\end{tabular}

Seluruh data data ditransformasi dengan rumus $\sqrt{x+0.5}$; Angka yang ditampilkan adalah nilai rataan sebelum transformasi; Nilai yang diikuti dengan huruf yang sama pada kolom yang sama menunjukkan tidak berbeda nyata berdasarkan DMRT pada $\alpha=5 \%$.

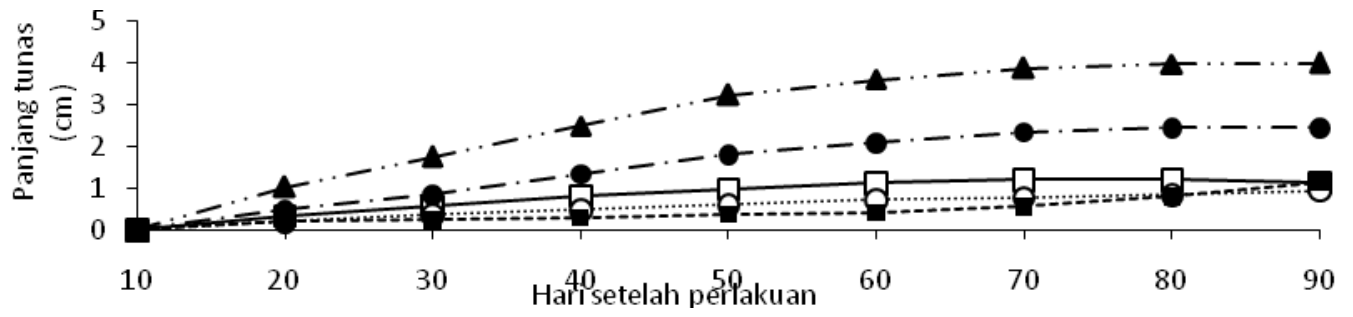

Gambar 1. Panjang tunas $K$. parviflora pada beberapa taraf konsentrasi BAP pada lot rimpang Cikabayan. -

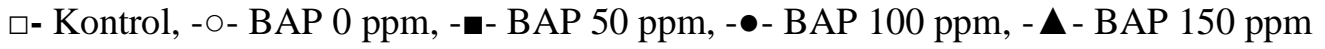

\section{Pengaruh Kondisi Asal Naungan terhadap Karakter Pertumbuhan Tunas RimpangK. Parviflora}

Rimpang yang berasal dari naungan tajuk pada lot Pasir Sarongge membutuhkan waktu yang lebih lama untuk bertunas dibandingkan naungan buatan 55\% (Tabel 3). Waktu rimpang bertunas pada lot Cikabayan tidak dipengaruhi oleh kondisi asal naungan pada penanaman sebelumnya, namun rimpang yang berasal dari naungan tajuk kehilangan bobot lebih besar dibandingkan naungan buatan 55\%. Hasil analisis ragam gabungan pada kedua lot menunjukkan bahwa rimpang yang berasal dari naungan tajuk juga memiliki waktu yang lebih lama untuk bertunas dan persentase penyusutan bobot yang 
lebih kecil dibandingkan rimpang yang berasal

dari naungan buatan $55 \%$.

Tabel 3. Pengaruh kondisi asal naungan terhadap waktu rimpang bertunas dan penyusutan bobot rimpang $K$. parviflora

\begin{tabular}{lccccccccc}
\hline \multirow{2}{*}{$\begin{array}{l}\text { Kondisi } \\
\text { asal naungan }\end{array}$} & \multicolumn{3}{c}{$\begin{array}{c}\text { Waktu rimpang } \\
\text { bertunas (HSP) }\end{array}$} & \multicolumn{3}{c}{$\begin{array}{c}\text { Penyusutan bobot } \\
\text { rimpang }(\mathrm{g})\end{array}$} & \multicolumn{3}{c}{$\begin{array}{c}\text { Persentase penyusutan } \\
\text { bobot (\%) }\end{array}$} \\
\cline { 2 - 12 } & Lot C & Lot PS & Rataan & Lot C & Lot PS & Rataan & Lot C & Lot PS & Rataan \\
\hline Naungan buatan 55\% & 28.4 & 25.9 & 27.2 & 3.01 & 5.62 & 4.41 & 33.00 & 30.08 & 31.45 \\
Naungan tajuk & 44.1 & 59.2 & 47.4 & 2.05 & 6.12 & 4.13 & 20.75 & 22.92 & 21.86 \\
\hline Uji-F & tn & $*$ & & $* *$ & tn & & $* *$ & $* *$ & $* *$ \\
Uji ragam gabungan & & & $*$ & & & tn & & & $* *$
\end{tabular}

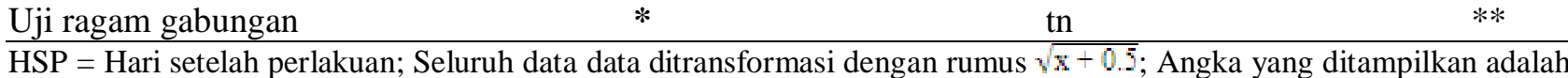
nilai rataan sebelum transformasi; $\mathrm{tn}=$ tidak berbeda nyata; $*=$ berbeda nyata pada $\alpha=5 \%$; $*$ = berbeda nyata pada $\alpha=$ $5 \%$.

Rimpang yang berasal dari naungan buatan 55\% pada lot Cikabayan memiliki jumlah tunas yang lebih banyak saat umur 50-60 HSP dibandingkan naungan tajuk (Tabel 4). Rimpang yang berasal dari naungan buatan 55\% pada lot Pasir Sarongge juga memiliki jumlah tunas yang lebih banyak saat umur 10-90 HSP dan tunas yang lebih panjang saat umur 30-80 HSP dibandingkan naungan tajuk.

Kondisi intensitas cahaya pada naungan tajuk telah diketahui lebih rendah dibandingkan pada naungan buatan 55\% (Evi 2012). Menurut Harjadi (1989), kelebihan intensitas cahaya dapat menurunkan hasil panen, mempengaruhi suhu daun dan mempengaruhi enzim tertentu sehingga menonaktifkan enzim yang mengubah pati ke gula. Hasil penelitian pada tanaman Arundinariagigantea menunjukkan bahwa penggunaan naungan dapat menghasilkan tunas, akar, dan rimpang yang lebih besar dibandingkan kondisi tanpa penggunaan naungan (Cirtain et al. 2009).

Tabel 4. Pengaruh kondisi asal naungan terhadap jumlah dan panjang tunas rimpang K. parviflora

\begin{tabular}{cccccc}
\hline \multirow{2}{*}{$\begin{array}{c}\text { Umur } \\
\text { (HSP) }\end{array}$} & \multicolumn{2}{c}{ Lot rimpang Cikabayan } & & \multicolumn{2}{c}{ Lot rimpang Pasir Sarongge } \\
\cline { 2 - 3 } \cline { 5 - 6 } & Naungan buatan 55\% & Naungan tajuk & Naungan buatan 55\% & Naungan tajuk \\
30 & 0.7 & 0.4 & & $1.1 \mathrm{a}$ & $0.1 \mathrm{~b}$ \\
40 & 0.8 & 0.5 & & $1.2 \mathrm{a}$ & $0.1 \mathrm{~b}$ \\
50 & $0.8 \mathrm{a}$ & $0.5 \mathrm{~b}$ & & $1.3 \mathrm{a}$ & $0.1 \mathrm{~b}$ \\
60 & $0.9 \mathrm{a}$ & $0.6 \mathrm{~b}$ & $1.3 \mathrm{a}$ & $0.1 \mathrm{~b}$ \\
70 & 1.0 & 0.6 & $1.3 \mathrm{a}$ & $0.1 \mathrm{~b}$ \\
80 & 1.0 & 0.8 & $1.5 \mathrm{a}$ & $0.2 \mathrm{~b}$ \\
90 & 1.0 & 0.9 & $1.6 \mathrm{a}$ & $0.2 \mathrm{~b}$ \\
\hline & & & & \\
30 & 0.71 & 0.78 & $0.84 \mathrm{a}$ & $0.07 \mathrm{~b}$ \\
40 & 1.00 & 1.16 & $1.14 \mathrm{a}$ & $0.14 \mathrm{~b}$ \\
50 & 1.33 & 1.44 & $1.43 \mathrm{a}$ & $0.25 \mathrm{~b}$ \\
60 & 1.57 & 1.60 & $1.70 \mathrm{a}$ & $0.37 \mathrm{~b}$ \\
70 & 1.74 & 1.75 & & $1.87 \mathrm{a}$ & $0.59 \mathrm{~b}$ \\
80 & 1.82 & 1.87 & $2.03 \mathrm{a}$ & $0.91 \mathrm{~b}$ \\
90 & 1.89 & 1.97 & 2.13 & 1.29 \\
\hline
\end{tabular}

HSP $=$ Hari setelah perlakuan; Seluruh data data ditransformasi dengan rumus $\sqrt[3]{\mathrm{X}+0.5}$; Angka yang ditampilkan adalah nilai rataan sebelum transformasi; Nilai yang diikuti dengan huruf yang sama pada baris yang sama pada tiap lot dan pada tiap peubah menunjukkan tidak berbeda nyata berdasarkan uji-F. 
Pengaruh Konsentrasi BAP dan Kondisi Asal Naungan terhadap Pertumbuhan Tanaman $K$. Parviflora

Hasil analisis ragam menunjukkan bahwa konsentrasi BAP dan kondisi asal naungan berpengaruh nyata terhadap beberapa karakter pertumbuhan tanaman $K$. parviflora pada umur tanaman tertentu, dan interaksi antara keduanya tidak berpengaruh nyata terhadap karakter pertumbuhan tanaman.Konsentrasi BAP sebesar 150 ppm pada rimpang lot Cikabayan menghasilkan jumlah dan tinggi tanaman yang lebih besar dibandingkan kontrol hingga 4 MST. Tanaman yang berasal dari lot Pasir Sarongge memperlihatkan pengaruh yang berbeda. Konsentrasi BAP sebesar 150 dan 0 ppm pada rimpang lot Pasir Sarongge menghasilkan tanaman yang lebih banyak sejak 5 MST dibandingkan taraf lainnya. Tanaman lot Pasir Sarongge memiliki jumlah tanaman yang tidak berbeda nyata saat umur 8 MST pada semua taraf, yaitu sebesar 5 tanaman per rumpun dengan ratarata tinggi tanaman sebesar $24.9 \mathrm{~cm}$.

Hasil penelitian ini menunjukkan bahwa aplikasi perendaman rimpang berpengaruh terhadap jumlah tanaman dan tinggi tanaman $K$. parviflora, meskipun tanpa penggunaan BAP. Jumlah tanaman per rumpun pada tanaman $K$. parviflora efektif meningkat sejak tanaman berumur 5 MST. Rahma (2013) melaporkan bahwa pertumbuhan tanaman $K$. parviflora dapat meningkat sampai umur 26 MST pada budi daya di lahan $240 \mathrm{~m}$ dpl dan sampai 35 MST di lahan 1 $200 \mathrm{~m} \mathrm{dpl}$.

Rimpang yang berasal dari naungan tajuk pada lot Cikabayan menghasilkan jumlah dan tinggi tanaman yang lebih besar dibandingkan naungan buatan 55\%. Rimpang yang berasal dari naungan buatan 55\% pada lot Pasir Sarongge menghasilkan tanaman yang lebih tinggi dibandingkan naungan tajuk. Hal tersebut menunjukkan bahwa kondisi asal naungan rimpang berpengaruh terhadap jumlah dan tinggi tanaman.

Konsentrasi BAP sebesar 150, 100, dan 0 ppm pada lot rimpang Pasir Sarongge menghasilkan daun tanaman yang lebih banyak, lebih panjang dan lebih lebar dibandingkan kontrol pada umur 8 MST. Konsentrasi BAP pada lot rimpang Cikabayan tidak berpengaruh terhadap pertumbuhan daun. Tanaman yang berasal dari lot rimpang Cikabayan pada 8 MST memiliki rata-rata jumlah daun sebanyak 1.3 dengan rata-rata panjang daun $9.2 \mathrm{~cm}$ dan ratarata lebar daun $5.2 \mathrm{~cm}$.

Kondisi asal naungan juga berpengaruh nyata terhadap jumlah daun saat tanaman berumur 3-5 MST untuk lot Pasir Sarongge, tetapi tidak berpengaruh nyata untuk lot rimpang Cikabayan. Rimpang yang berasal dari naungan tajuk menghasilkan daun yang lebih panjang dibandingkan naungan buatan $55 \%$ di akhir pengamatan pertumbuhan, meskipun dengan lebar daun yang lebih kecil di awal pertumbuhan.

Hasil menunjukkan bahwa aplikasi perendaman pada rimpang dapat meningkatkan panjang dan lebar daun $K$. parviflora, walaupun tanpa penambahan BAP. Kondisi asal naungan buatan 55\% pada lot Pasir Sarongge dapat menghasilkan panjang dan lebar daun yang lebih besar dibandingkan asal naungan tajuk. Kondisi asal naungan pada lot Cikabayan menghasilkan pengaruh sebaliknya. Hal tersebut dikarenakan terdapat hama dan patogen yang menyerang sebagian besar tanaman dari lot Cikabayan pada awal pertubuhan, sehingga pertumbuhan tanaman terganggu. Penanggulangan hama dan patogen dilakukan secara manual. Rimpang yang berasal dari naungan buatan 55\% dengan aplikasi konsentrasi BAP sebesar 50 ppm dapat memproduksi jumlah daun yang paling banyak pada awal pertumbuhan vegetatif.

\section{Percobaan 2: Pematahan Dormansi Rimpang Kaempferia parvifloraWallEx.Baker dengan Etepon}

Pengaruh KonsentrasiEtepon terhadap Karakter Pertumbuhan TunasRimpangK. Parviflora

Konsentrasi etepon tidak berpengaruh nyata terhadap waktu rimpang bertunas, jumlah tunas, panjang tunas, dan penyusutan bobot rimpang (Tabel 5). Paz (2003) melaporkan bahwa penggunaan etepon tidak efektif dalam mempercepat pertunasan rimpang $C$. cordata. Thohirah et al. (2010) melaporkan sebaliknya bahwa konsentrasi etepon sebesar 600 ppm dapat mempercepat waktu bertunas $C$. alismatifolia sebesar 2.5 hari lebih cepat dibandingkan rimpang yang tidak diberi etepon. Hasil penelitian ini menunjukkan bahwa etepon sampai dengan konsentrasi $800 \mathrm{ppm}$ belum cukup efektif menstimulasi waktu rimpang $K$. parviflora bertunas. Rimpang dengan konsentrasi etepon sebesar 600, 400, 200 dan 0 ppm memiliki persentase penyusutan bobot lebih sedikit dibandingkan kontrol, meskipun tidak berbeda 
nyata terhadap konsentrasi etepon 800 ppm Hasil analisis ragam gabungan menunjukkan bahwa rimpang lot Pasir Sarongge kehilangan bobot lebih besar dibandingkan rimpang lot Cikabayan.

Tabel 5. Pengaruh konsentrasi etepon terhadap waktu rimpang bertunas dan penyusutan bobot rimpang

\begin{tabular}{llllllllll}
\hline $\begin{array}{l}\text { Konsentrasi } \\
\text { etepon } \\
\text { (ppm) }\end{array}$ & \multicolumn{3}{c}{$\begin{array}{c}\text { Waktu rimpang } \\
\text { bertunas (HSP) }\end{array}$} & \multicolumn{3}{c}{$\begin{array}{c}\text { Penyusutan } \\
\text { bobot rimpang }(\mathrm{g})\end{array}$} & \multicolumn{3}{c}{$\begin{array}{c}\text { Persentase penyusutan } \\
\text { bobot rimpang(\%) }\end{array}$} \\
\cline { 2 - 10 } & Lot C & Lot PS & Rataan & Lot C & Lot PS & Rataan & Lot C & Lot PS & Rataan \\
\hline Kontrol & 30.0 & 35.2 & 31.5 & 3.08 & 7.11 & 5.10 & 31.70 & $31.60 \mathrm{a}$ & 31.65 \\
0 & 39.3 & 54.0 & 35.7 & 2.48 & 5.89 & 4.18 & 25.70 & $23.60 \mathrm{~b}$ & 24.65 \\
200 & 27.0 & 45.5 & 37.0 & 1.91 & 5.18 & 3.66 & 20.55 & $22.60 \mathrm{~b}$ & 21.57 \\
400 & 36.8 & 27.3 & 36.3 & 4.73 & 4.62 & 4.67 & 39.87 & $19.30 \mathrm{~b}$ & 29.58 \\
600 & 57.7 & 51.7 & 52.8 & 3.34 & 5.71 & 4.52 & 30.80 & $21.40 \mathrm{~b}$ & 26.10 \\
800 & 37.5 & 23.0 & 27.8 & 3.10 & 6.72 & 4.91 & 28.70 & $25.00 \mathrm{ab}$ & 26.85 \\
\hline Rataan & 37.6 & 36.1 & & $3.08 \mathrm{~B}$ & $5.87 \mathrm{~A}$ & & 29.35 & 23.91 &
\end{tabular}

HSP = Hari setelah perlakuan; $\mathrm{C}=$ Cikabayan; PS = Pasir Sarongge; Seluruh data ditransformasi dengan rumus $\sqrt{\mathrm{x}+0.5}$; Angka yang ditampilkan adalah nilai rataan sebelum transformasi; Nilai yang diikuti dengan huruf yang sama pada kolom yang sama menunjukkan tidak berbeda nyata berdasarkan DMRT pada $\alpha=5 \%$. Nilai yang diikuti dengan huruf kapital yang sama pada tiap peubah menunjukkan tidak berbeda nyata berdasarkan analisis ragam gabungan.

Pengaruh Kondisi Asal Naungan terhadap Karakter Pertumbuhan Tunas RimpangK. Parviflora

Hasil analisis ragam gabungan menunjukkan bahwa rimpang yang berasal dari naungan tajuk memiliki waktu rimpang bertunas yang lebih lama dibandingkan rimpang yang berasal dari naungan buatan 55\%. Rimpang lot Pasir Sarongge yang berasal dari naungan buatan 55\% memiliki tunas yang lebih banyak dan lebih panjang dibandingkan rimpang yang berasal dari naungan tajuk (Tabel 6).

Tabel 6. Pengaruh kondisi asal naungan terhadap jumlah dan panjang tunas rimpang $K$. parviflora

\begin{tabular}{|c|c|c|c|c|}
\hline \multirow{2}{*}{$\begin{array}{l}\text { Umur } \\
\text { (HSP) }\end{array}$} & \multicolumn{2}{|c|}{ Lot rimpang Cikabayan } & \multicolumn{2}{|c|}{ Lot rimpang Pasir Sarongge } \\
\hline & Naungan buatan 55\% & Naungan tajuk & Naungan buatan 55\% & Naungan tajuk \\
\hline & \multicolumn{4}{|c|}{ Jumlah tunas per rimpang ${ }^{\mathrm{t}}$} \\
\hline 50 & $0.9 \mathrm{a}$ & $0.4 \mathrm{~b}$ & $1.2 \mathrm{a}$ & $0.2 b$ \\
\hline 70 & $0.9 \mathrm{a}$ & $0.4 \mathrm{~b}$ & $1.6 \mathrm{a}$ & $0.3 b$ \\
\hline 90 & $1.1 \mathrm{a}$ & $0.6 \mathrm{~b}$ & $1.9 \mathrm{a}$ & $0.4 b$ \\
\hline \multicolumn{5}{|c|}{ Panjang tunas $(\mathrm{cm})^{\mathrm{T}}$} \\
\hline 80 & 1.64 & 0.92 & $2.07 \mathrm{a}$ & $0.85 b$ \\
\hline 90 & 1.71 & 1.00 & $2.21 \mathrm{a}$ & $0.97 \mathrm{~b}$ \\
\hline
\end{tabular}

HSP $=$ Hari setelah perlakuan; $\mathrm{t}=$ data ditransformasi dengan rumus $\sqrt{\mathrm{x}+0.5} ; \mathrm{T}=$ data ditransformasi dengan rumus $\sqrt{\mathrm{x}+1.0}$; Angka yang ditampilkan adalah nilai rataan sebelum transformasi; Nilai yang diikuti dengan huruf yang sama pada baris yang sama pada tiap lot rimpang dan pada tiap peubah menunjukkan tidak berbeda nyata berdasarkan Uji-F.

Pengaruh Konsentrasi Etepon dan Asal Naungan terhadap Pertumbuhan Tanaman K. Parviflora

Konsentrasi etepon sebesar 800 ppm menghasilkan jumlah dan tinggi tanaman yang lebih besar dibandingkan kontrol, namun tidak berbeda nyata terhadap konsentrasi 0 ppm (Tabel 7). Hal tersebut menunjukkan bahwa perlakuan perendaman rimpang berpengaruh terhadap jumlah dan tinggi tanaman, meskipun tanpa penambahan etepon.

Kondisi asal naungan tajuk pada lot Cikabayan menghasilkan tanaman yang lebih banyak dan lebih tinggi dibandingkan naungan buatan pada akhir pengamatan pertumbuhan tanaman. Kondisi sebaliknya terjadi pada awal pertumbuhan tanaman. Hal tersebut dikarenakan terdapat hama kutu putih yang menyerang tanaman lot Cikabayan di awal pertumbuhan. Pengendalian hama dan dilakukan secara manual pada tanaman yang terserang. Kondisi asal naungan buatan 55\% pada lot Pasir Sarongge menghasilkan jumlah dan tinggi tanaman yang lebih besar di awal pertumbuhan, tetapi lebih kecil di akhir pengamatan pertumbuhan dibandingkan naungan tajuk. Hal tersebut menunjukkan bahwa 
kondisi naungan tajuk rimpang mampu lebih tinggi. menghasilkan tanaman yang lebih banyak dan

Tabel 7. Pengaruh kondisi asal naungan rimpang terhadap pertumbuhan tanaman K. parviflora

\begin{tabular}{llllccccccc}
\hline \multirow{2}{*}{ Lot rimpang } & Kondisi & \multicolumn{7}{c}{ Umur tanaman (minggu setelah tanam) } \\
\cline { 2 - 9 } & asal naungan & 1 & 2 & 3 & 4 & 5 & 6 & 7 & 8 \\
\hline \multirow{2}{*}{ Cikabayan } & Naungan buatan 55\% & $0.4 \mathrm{a}$ & 0.4 & 0.5 & 0.6 & $1.1 \mathrm{~b}$ & 1.4 & 1.5 & 1.5 \\
& Naungan tajuk & $0.1 \mathrm{~b}$ & 0.2 & 0.6 & 1.1 & $1.6 \mathrm{a}$ & 1.7 & 1.8 & 2.0 \\
Pasir & Naungan buatan 55\% & $1.0 \mathrm{a}$ & $1.8 \mathrm{a}$ & 3.1 & 4.3 & $5.7 \mathrm{~b}$ & $6.7 \mathrm{~b}$ & $7.0 \mathrm{~b}$ & $7.0 \mathrm{~b}$ \\
Sarongge & Naungan tajuk & $0.5 \mathrm{~b}$ & $0.6 \mathrm{~b}$ & 3.5 & 5.9 & $9.2 \mathrm{a}$ & $9.4 \mathrm{a}$ & $9.7 \mathrm{a}$ & $9.7 \mathrm{a}$ \\
\hline \multirow{3}{*}{ Cikabayan } & & \multicolumn{7}{c}{ Tinggi tanaman $(\mathrm{cm})$} \\
& Naungan buatan 55\% & 1.0 & 1.2 & 1.6 & 2.4 & 4.2 & $7.8 \mathrm{~b}$ & $11.2 \mathrm{~b}$ & $14.6 \mathrm{~b}$ \\
Pasir & Naungan tajuk & 0.4 & 0.7 & 1.8 & 3.8 & 8.2 & $14.3 \mathrm{a}$ & $20.1 \mathrm{a}$ & $23.8 \mathrm{a}$ \\
Sarongge & Naungan buatan 55\% & $2.1 \mathrm{a}$ & $5.4 \mathrm{a}$ & $9.7 \mathrm{a}$ & $14.0 \mathrm{a}$ & 18.8 & 24.6 & 27.2 & 29.6 \\
\hline & Naungan tajuk & $0.6 \mathrm{~b}$ & $1.3 \mathrm{~b}$ & $3.9 \mathrm{~b}$ & $7.0 \mathrm{~b}$ & 15.1 & 18.8 & 23.4 & 27.4 \\
\hline
\end{tabular}

Nilai yang diikuti dengan huruf yang sama pada kolom yang sama pada tiap lot dan pada tiap peubah menunjukkan tidak berbeda nyata berdasarkan DMRT pada taraf $\alpha=5 \%$.

Konsentrasi etepon sebesar $400 \mathrm{ppm}$ pada lot Pasir Sarongge mampu menghasilkan jumlah daun yang lebih banyak dibandingkan taraf konsentrasi lainnya saat umur 4 MST, namun tidak berbeda nyata dengan konsentrasi 600 ppm. Seluruh konsentrasi etepon pada umur 7 MST menghasilkan jumlah daun, panjang daun, dan lebar daun yang tidak berbeda nyata dibandingkan kontrol. Jumlah daun, panjang daun, dan lebar daun tanaman pada lot Cikabayan tidak dipengaruhi oleh konsentrasi etepon.

Naungan buatan $55 \%$ pada lot rimpang Pasir Sarongge menghasilkan jumlah daun, panjang daun dan lebar daun yang lebih besar dibandingkan naungan tajuk saat umur tanaman 35 MST. Rimpang yang berasal dari naungan tajuk pada lot Cikabayan menghasilkan panjang dan lebar daun yang lebih besar dibandingkan rimpang yang berasal dari naungan buatan $55 \%$ saat umur 6-8 MST, namun tidak terdapat perbedaan yang nyata terhadap jumlah daun.
Perbandingan Dua Lot Rimpang terhadap Pertumbuhan Tunas Rimpang dan Tanaman K. Parviflora

Kedua lot rimpang Cikabayan dan Pasir Sarongge dibandingkan untuk mengetahui pengaruh kondisi penanaman terhadap pertumbuhan tunas rimpang $K$. parviflora. Hasil menunjukkan bahwa kedua lot memiliki nilai yang tidak berbeda nyata terhadap waktu rimpang bertunas, jumlah tunas, dan panjang tunas, namun rimpang pada lot Pasir Sarongge memiliki penyusutan bobot yang lebih besar dibandingkan rimpang pada lot Cikabayan (Tabel 8). Hal tersebut menunjukkan bahwa rimpang pada lot Pasir Sarongge kehilangan bobot yang lebih besar selama pertumbuhan tunas dibandingkan rimpang pada lot Cikabayan.

Tabel 8. Perbandingan kedua lot rimpang pada karakter pertumbuhan dan perkembangan rimpang $K$. parviflora

\begin{tabular}{lccccc}
\hline Parameter & $\begin{array}{c}\text { Umur } \\
\text { (HSP) }\end{array}$ & $\begin{array}{c}\text { Lot } \\
\text { Cikabayan }\end{array}$ & $\begin{array}{c}\text { Lot } \\
\text { Pasir Parongge }\end{array}$ & Uji-t & Nilai-t \\
\hline Waktu rimpang bertunas (HSP) & - & 35.67 & 32.31 & tn & 0.48 \\
Jumlah tunas & 90 & 0.96 & 0.90 & tn & 0.34 \\
Panjang tunas (cm) & 90 & 1.93 & 1.87 & tn & 0.17 \\
Penyusutan bobot (g) & 90 & $2.51 \mathrm{~b}$ & $5.88 \mathrm{a}$ & $* *$ & -7.72 \\
\hline
\end{tabular}

HSP $=$ hari setelah perlakuan; tn $=$ tidak berbeda nyata; $*$ = berbeda nyata pada $\alpha=5 \%$; $*$ = berbeda nyata pada $\alpha=$ $1 \%$; Nilai yang diikuti huruf yang sama pada baris yang sama tidak berbeda nyata berdasarkan uji-t.

Rahma (2013) melaporkan bahwa perbedaan kondisi kedua lot pada penanaman sebelumnya telah mempengaruhi perbedaan laju pertumbuhan, jumlah klorofil, waktu panen, 
produksi rimpang, bahan aktif terkandung pada rimpang $K$. parviflora. Tanaman dengan tinggi, jumlah daun, dan lebar daun yang lebih besar memiliki efisiensi metabolisme yang lebih besar. Hal tersebut dapat membantu dalam pembentukan rimpang. Menurut Sanewski et al. (1996) bagian rimpang yang lebih muda pada tanaman jahe (Zingiberofficinale) memiliki periode dormansi yang lebih lama dibandingkan bagian rimpang yang lebih dewasa.

Paz (2003) melaporkan bahwa waktu pemunculan tunas pada tanaman C. alismatifolia juga dapat dipercepat oleh jumlah akar tuberous (t-roots) yang lebih banyak. Menurut Hartmann dan Kester (1959) rimpang yang berukuran besar dan memiliki akar adventif dapat lebih mudah tumbuh menjadi tanaman. Rahma (2013) melaporkan bahwa $K$. parviflora memiliki struktur akar gemuk (fleshyroot) yang menyerupai akar tuberous pada tanaman C. alismatifolia. Struktur akar gemuk $K$. parviflora dipisahkan dari rimpang, dan hanya bagian rimpang yang digunakan dalam penelitian ini. Oleh karena itu diduga bahwa tanpa akar gemuk, waktu pemunculan tunas $K$. parviflora lebih menjadi lebih lama.Tanaman yang berasal dari lot rimpang Pasir Sarongge memiliki jumlah tanaman per rumpun, tinggi tanaman, jumlah daun, panjang daun, serta lebar daun yang lebih tinggi dibandingkan lot Cikabayan (Tabel 9).

Tabel 9. Perbandingan antara kedua lot rimpang pada karakter pertumbuhan tanamanK. parviflora

\begin{tabular}{lccccc}
\hline Parameter & $\begin{array}{c}\text { Umur tanaman } \\
(\text { MST })\end{array}$ & $\begin{array}{c}\text { Lot } \\
\text { Cikabayan }\end{array}$ & $\begin{array}{c}\text { Lot } \\
\text { Pasir Sarongge }\end{array}$ & Uji-t & Nilai-t \\
\hline Jumlah & 2 & 0.63 & 0.85 & tn & -1.14 \\
tanaman per & 4 & $1.00 \mathrm{~b}$ & $3.18 \mathrm{a}$ & $* *$ & -4.70 \\
rumpun & 6 & $1.40 \mathrm{~b}$ & $5.88 \mathrm{a}$ & $* *$ & -5.95 \\
& 8 & $1.63 \mathrm{~b}$ & $6.39 \mathrm{a}$ & $* *$ & -5.84 \\
\hline Tinggi tanaman & 2 & $1.49 \mathrm{~b}$ & $3.24 \mathrm{a}$ & $*$ & -2.02 \\
& 4 & $2.66 \mathrm{~b}$ & $8.62 \mathrm{a}$ & $* *$ & -3.88 \\
& 6 & $10.35 \mathrm{~b}$ & $18.53 \mathrm{a}$ & $* *$ & -3.64 \\
& 8 & $16.43 \mathrm{~b}$ & $24.72 \mathrm{a}$ & $* *$ & -3.24 \\
\hline Jumlah daun & 2 & $0.00 \mathrm{~b}$ & $0.12 \mathrm{a}$ & $*$ & -2.10 \\
& 4 & $0.03 \mathrm{~b}$ & $0.52 \mathrm{a}$ & $* *$ & -3.62 \\
& 6 & $0.54 \mathrm{~b}$ & $0.94 \mathrm{a}$ & $* *$ & -2.68 \\
\hline Panjang daun & 8 & 1.26 & 1.18 & tn & 0.39 \\
\hline Lebar daun & 2 & 0.00 & 0.85 & tn & -2.02 \\
& 4 & $0.27 \mathrm{~b}$ & $3.66 \mathrm{a}$ & $* *$ & -3.47 \\
& 6 & $5.38 \mathrm{~b}$ & $9.21 \mathrm{a}$ & $*$ & -2.53 \\
& 8 & $9.17 \mathrm{a}$ & $13.37 \mathrm{~b}$ & $* *$ & -2.68 \\
\hline
\end{tabular}

MST $=$ Minggu setelah tanam; tn $=$ tidak berbeda nyata; $*=$ berbeda nyata pada $\alpha=5 \% ; * *=$ berbeda nyata pada $\alpha=$ $1 \%$. Nilai yang diikuti huruf yang sama pada baris yang sama tidak berbeda nyata berdasarkan uji-t.

\section{KESIMPULAN}

Konsentrasi BAP sampai dengan 150 ppm belum cukup efektif menstimulasi pemunculan tunas rimpang $K$. parviflora. Konsentrasi etepon sampai dengan $800 \mathrm{ppm}$ juga belum efektif menstimulasi pertumbuhan tunas rimpang $K$. parviflora. Kondisi asal naungan pada penanaman sebelumnya berpengaruh nyata terhadap pertumbuhan tunas rimpang. Naungan buatan 55\% menghasilkan waktu bertunas rimpang yang lebih cepat dibandingkan naungan tajuk, namun naungan tajuk menghasilkan tanaman yang lebih banyak, lebah tinggi dan daun yang lebih panjang dan lebar dibandingkan naungan buatan 55\%. Tanaman yang berasal dari lot rimpang Pasir Sarongge memiliki jumlah tanaman, tinggi tanaman, jumlah daun, panjang daun, dan lebar daun yang lebih besar dibandingkan tanaman dari lot rimpang Cikabayan. 


\section{DAFTAR PUSTAKA}

Chaichanawongsaroj, N., Amonyingcharoen S., Pattiyathanee P., Vilaichone R-k, Poovorawan Y. 2011. Anti-Helicobacter pylori and anti-internalization activities of Thai folk remedies used to treat gastric ailments. J Med Plants Res. 6(8):1389-1393.

Cirtain, M.C., Franklin S.B., Pazeshki S.R. 2009. Effect of light intensity on Arundinaria gigantea growth and physiology. Castanea. 74(3):236-246.

Djamhari, S. 2010. Memecah dormansi rimpang temulawak (Curcuma xanthorrhiza ROXB) menggunakan larutan atonik dan stimulasi perakaran dengan aplikasi auksin. JSTI. 12(1): 66-70.

Evi. 2012. Altitude and shading conditions affect vegetative growth of Kaempferia parviflora [skripsi]. Bogor (ID): Institut Pertanian Bogor (IPB).

Handoko. 1993. Klimatologi Dasar. Jakarta (ID): Pustaka Jaya.

Harjadi, S. 1989. Dasar-dasar Hortikultura. Bogor (ID): Jurusan Budidaya Pertanian Faperta, IPB.

Hartmann, H.T., Kester D.E. 1959. Plant Propagation: Principles and Practices. Englewood Cliffs (US): Prentice-Hall.

Heddy, S. 1986. Hormon Tumbuhan. Jakarta (ID): Rajawali.

Indriati. 2006. Pengaruh jadwal irigasi terhadap pertumbuhan dan produksi kencur [skripsi]. Bogor (ID): Institut Pertanian Bogor (IPB).

Leardkamolkarn, V., Tiamyuyen S., Sripanidkulchai $\quad$ B-o. 2009. Pharmacological activity of Kaempferia parviflora against human bile duct cancer cell lines. Asian Pacific J Cancer Prev. 10:695-698.

Paz, M.D.P. 2003. Rhizome manipulation affects growth and development of ornamental gingers [tesis]. Baton Rouge (US): Louisiana State University and Agricultural and Mechanical College (LSU).

Rahma, A. 2013. Analisis produksi dan kandungan bahan aktif Kaempferia parviflora Wall ex. Baker pada ketinggian dan tingkat naungan yang berbeda [skripsi]. Bogor (ID): Institut Pertanian Bogor.

Rostiana, O., Effendi D.S. 2007. Teknologi Unggulan Kencur : Perbenihan dan Budidaya Pendukung Varietas Unggul. Bogor (ID): Pusat Penelitian dan Pengembangan Perkebunan.

Sanewski, G.M., Fukain S., Giles J. 1996. Shoot emergence of ginger (Zingiber officinale Roscoe) as affected by time of lifting, storage, size and type of planting pieces. Trop Agric. 73(4):286-291.

Techaprasan, J., Klinbunga S., Ngamriabsakul C., Jenjittikul T. 2010. Genetic variation of Kaempferia (Zingiberaceae) in Thailand based on chloroplast DNA (psbA-trnH and petA-psbJ) sequences. Genet. Mol. Res. 9(4):1957-1973.

Tewtrakul, S., Subhadhirasakul S., Karalai C., Ponglimanont C, Cheenpracha S. 2009. Anti-inflammatory effects of compounds from Kaempferia parviflora and Boesenbergia pandurata. J Food Chem. 115:534-538.

Thohirah, L.A., Flora C.L.S., Kamalakshi N. 2010. Breaking bud dormancy and different shade levels for production of pot and cut Cucurma alismatifolia. Am J Agri Biol Sci. 53:385-388.

Zulfa, U. 2012. Application of liquid bio-fertilizer affected plant growth and rhizome production of black galingale (Kaempferia parviflora Wall ex. Baker) [skripsi]. Bogor (ID): Institut Pertanian Bogor (IPB). 